\title{
(C) Montreal's Cité-Jardin du Tricentenaire Transformation: The Role of the PIIA as a Tool for Resilience
}

\author{
Sylvie Paré \\ Department of Urban Studies and Tourism, The University of Quebec in Montreal's (UQAM), Canada
}

Copyright $(2016$ by authors, all rights reserved. Authors agree that this article remains permanently open access under the terms of the Creative Commons Attribution License 4.0 International License

\begin{abstract}
This research focuses on the impact of the implementation of a by-law in a residential area, Montreal's garden city, la Cité-Jardin du Tricentenaire. The City of Montreal has implemented a set of specific architectural and environmental rules (PIIA, a Plan for Architectural Integration and Establishment) in order to protect and preserve the unique character of this Garden City built during the 1940's. In the general plan, Montreal designated the area as an exceptional site for preservation, a natural urban area and an authentic neighbourhood inspired by Ebenezer Howard's Garden City. In spite of the requirements of the PIIA for la Cité-Jardin, the recommendations of the Heritage Council of Montreal and the pressure exerted by the Residents' Association, a neutral observer might well conclude that not enough has been done to preserve the unique character of this neighborhood nor to prevent major transformations. The signs of decline in the quality of this heritage neighborhood have continued unabated during the 2010's: (1) significant enlargement of original houses, (2) demolition of heritage houses and reconstruction with only minimal, superficial similarities and (3) destruction of mature trees and replacement with suburban-style landscaping. While similar in some respects to the process of gentrification, the demographic changes underway in the Cite-Jardin are being produced by newcomers of a similar social class to the original residents but with a distinctly lower sensitivity to heritage architecture and community norms. Our research project aims to understand the effect of the PIIA as a potential catalyst for resilience in a case study, the Cité-Jardin du Tricentenaire community. Given the decentralized structure of the City of Montreal, bylaws governing the community are the responsibility of the Borough of Rosemont-La Petite-Patrie. This paper focuses principally on documentary analysis and interviews with borough officials designed to substantiate the theoretical structure underlying our approach.
\end{abstract}

Keywords Garden-city, Neighborhood Transition,
Urban Résilience, Consultation Process, Public Participation

\section{Introduction}

The Cité-Jardin du Tricentenaire of Montreal is a residential area in the eastern central part of the city of Montreal. Built during the 1940's on agricultural land, the Cité-Jardin project was initiated by a French Canadian, Roman Catholic cooperative group which was part of the City Improvement League. The historical background in which the Cité-Jardin was conceived included lack of jobs, lack of affordable housing for young families and the need of a model of planning to meet the needs of French Canadian, working class families. Nonetheless, most of the housing was sold to members of the « petite bourgeoisie » and liberal professions since working class people did not have sufficient disposable income to afford the housing being built in the area. As with many projects guided by lofty ideals, this one was derailed by poor management.

Conceived along the principles of the City Beautiful Movement, the Cité-Jardin constitutes a wonderful testimony to the vision and the quality of ideas developed by Ebenezer Howard (1902). The physical plan for the neighborhood included pedestrian paths, curved streets and $\mathrm{P}$ loop streets to separate different means of circulation. Automobiles were restricted to the dead-end cul-de-sacs while pedestrian walkways between each street and the central park permitted bicycles and pedestrians to circulate freely within the limits of the development. The original plan for the Cité-Jardin included a much larger area, from Viau to Lacordaire, Rosemont to Sherbrooke (Choko, 1988; Gilliland, 1996). The current neighborhood represents less than a quarter of the original project, that which is located in the upper left-hand corner of Figure 1. 
Un projet en voie de réalisation

$1642-$ CITE JARDIN TRICENTENAIRE - 1982

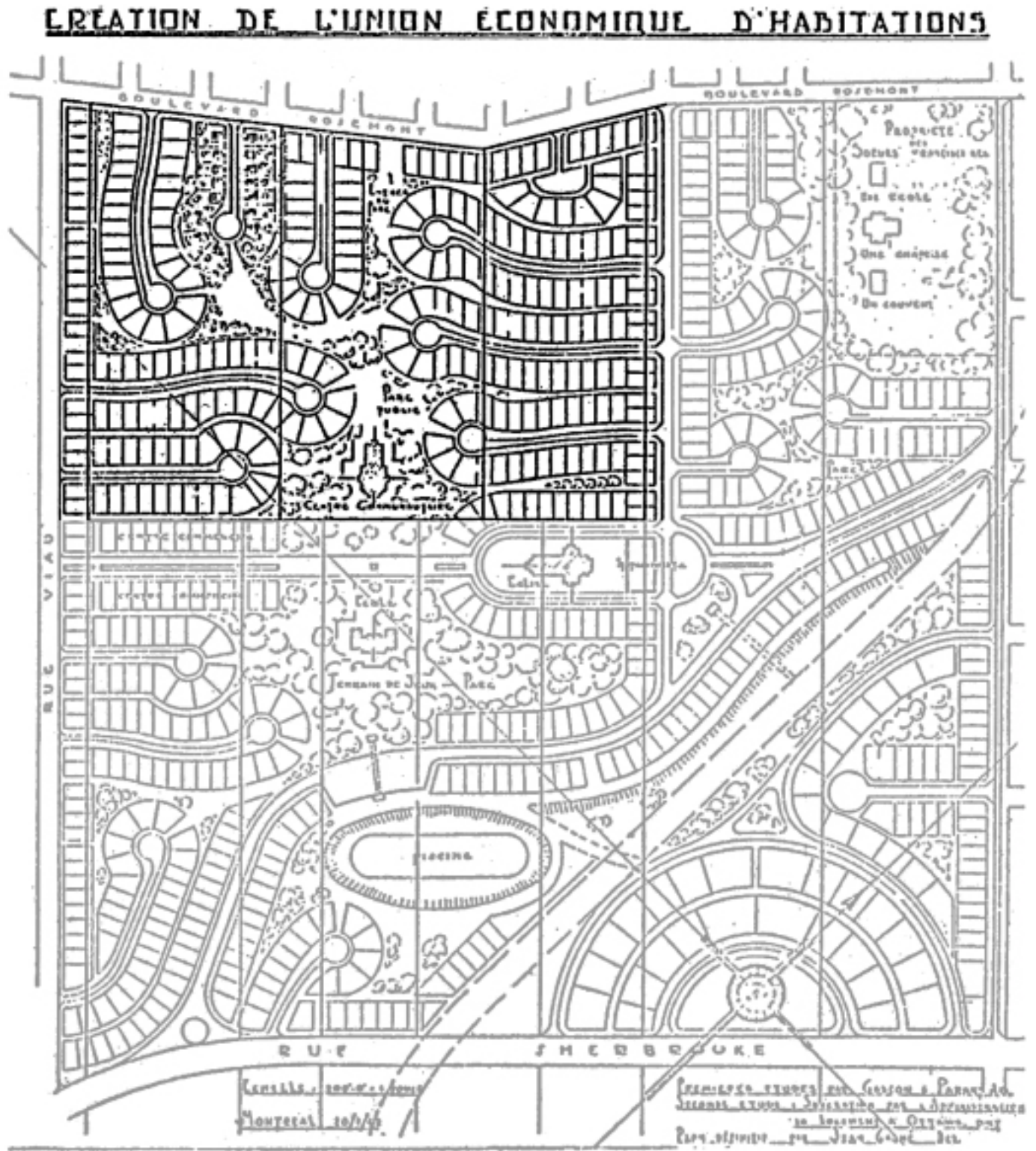

Source: Archives La Presse, 1942

Figure 1. The Plan of Cité-Jardin du Tricentenaire (1942)

According to the Conseil du patrimoine (2008) ${ }^{1}$, the Cité-Jardin du Tricentenaire enjoys exceptional historical and heritage value as reflected in the City Plans $(2004,2014)$ and possesses significant architectural unity, based upon an exceptional relationship between its buildings and the natural environment. Each street is named after the type of tree which characterizes it, adding to the uniqueness of the area. The community has always enjoyed a relatively high level of social cohesion with respect to its essential physical characteristics: the preservation of the pathways leading

1 The Heritage Council issues opinions on the value of historic sites, buildings and monuments of the City of Montreal. from each street to the central park; the emphasis on small footprint housing and a relatively high degree of greenery (trees, bushes, flowers and grass); direct contact between streets and green space without the interference of sidewalks and curbs; commitment to the preservation of the three traditional styles of architecture, including their stucco exteriors, a feature which still characterizes the large majority of housing in the neighborhood. Obviously, the common use of park space has led to a significant degree of contact between residents of the different streets composing the garden city, which facilitated the development of continued social cohesion more akin to gemeinschaft than 
gesellschaft.

The Cité-Jardin du Tricentenaire has always been recognized for its unique characteristics leading to a high quality of life for its residents. In this paper we theorize that the entire neighborhood area is undergoing a transition which has led to major adjustments within the community, bearing some similarity to the process of resilience observed in areas which have suffered natural disasters. While also similar in some respects to the process of gentrification, where working class is progressively replaced by population of higher education and revenue (Blais 2013), the demographic changes underway in la Cité-Jardin are being produced by newcomers of a similar social class to the original residents but with a distinctly lower sensitivity to heritage architecture and community values. We theorize that the adoption of the PIAA bylaws (Plan for Architectural Integration and Establishment ${ }^{2}$ ) by the Borough of Rosemont-La Petite Patrie was designed to regulate, stabilize and "normalize" the process of proposed renovations to the housing stock and serves as the departure point for a plan to promote social peace and a certain type of "return to the status quo" (or stability), typical of urban resilience movements.

\section{The Process of Resilience}

We hypothesize that the model of urban resilience is well suited to explain the evolution of both disintegration within the community and attempts to construct social norms re-establishing certain community values with respect to both the physical and social environment. The model which guides our research is derived from Jébrak (2010). Figure 2 illustrates the various components of this concept: governance networks, built environment, social dynamics and metabolic flows. Our research does not focus on this latter aspect but solely on the three former.
Given what we have outlined as indicators of a major transformation in the Cité-Jardin, we shall employ the methodology and concepts used when examining the resilience of areas affected by various types of disasters because this framework integrates both temporal and structural factors in the development of urban resilience. The application of the theory of urban resilience requires the identification of the period of a socially perturbing event, of a period of adaptation and of a period of a return to normality. We have identified these elements as follow:

- The period of stability is associated with the evolution of gemeinschaft ${ }^{3}$ as a unifying theme in the Cité-Jardin du Tricententaire. For approximately forty years, the neighborhood was characterized by the "normal" replacement of the population by people who shared the values of the established community;

- The period of disruption, characterized by a large increase in the number of real estate transactions, corresponds with (1) a rapid growth of the value of the housing stock, (2) an increase in the volume (bulk) of renovated and/or rebuilt homes, (3) a corresponding increase in the housing footprint in comparison to lot size, (4) a decline in social cohesion and (5) an increase in gesellschaft as the dominant value within the neighborhood;

- The period of social readjustment is characterized by the development of a new modus vivendi, defined by the development of a property owners' association and the creation and adoption of the PIIA bylaws designed to harmonize the aspirations of newcomers with the more traditional values of long-standing residents.
2 The PIIA « Plan d'implantation et d'intégration architecturale », is a bylaw which imposes obligations to respect certain architectural characteristics, including the size, volume and disposition on residential lots in neighborhoods whose special, heritage characteristics have been recognized by designated authorities.
3 "Gemeinschaft et Gesellschaft are "ideal types " in sociological discourse to define two types of human association (Ferdinand Tönnies, 1887). Gemeinschaft signifies « community » while Gesellschaft typifies « society », a more heterogeneous and less unified type of group. 


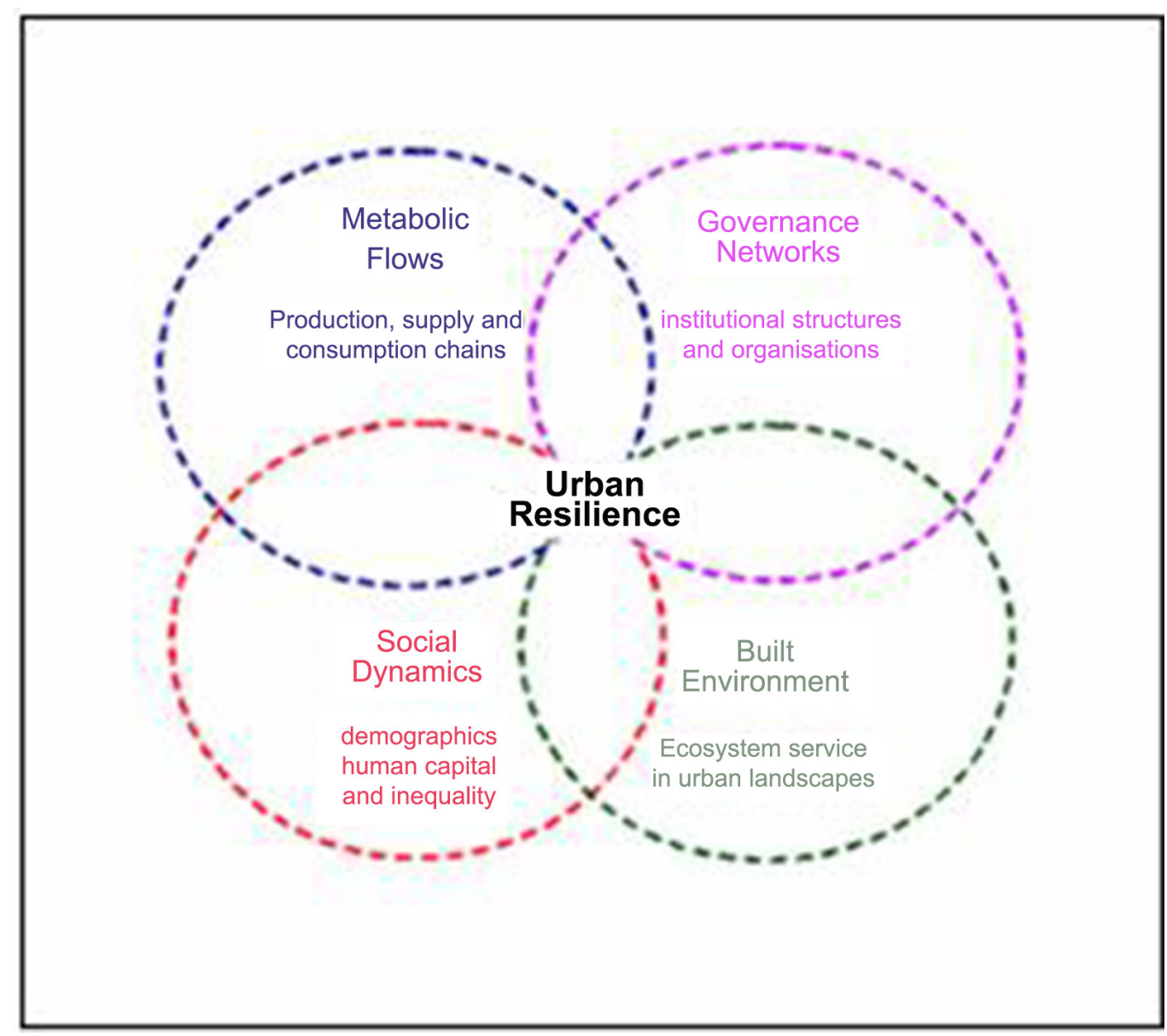

Figure 2. Components of resilience (Jébrak, 2010)

\section{Readjustment process}

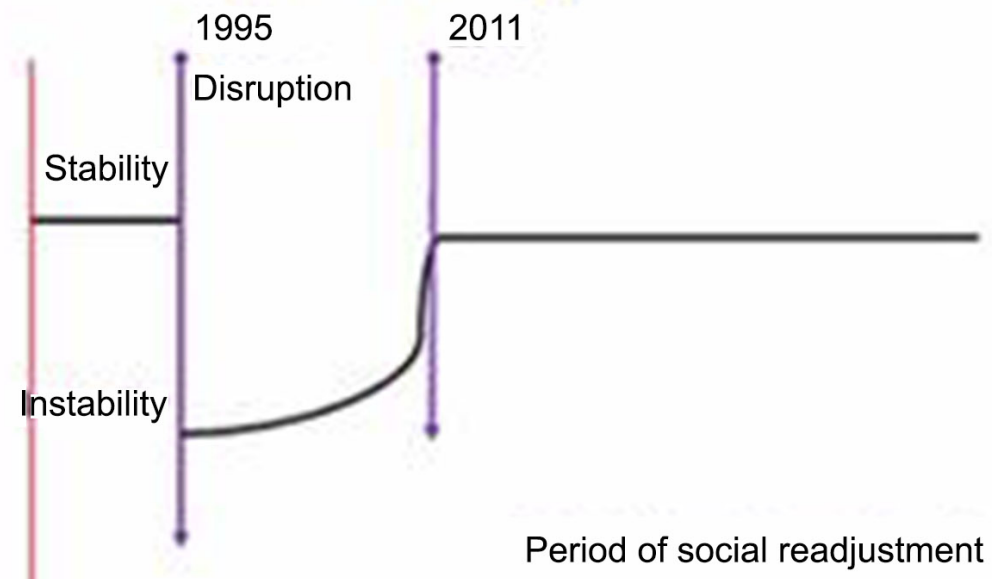


Our theoretical approach examines «consensual planning» for resilience ${ }^{4}$ (Kaufman, 2012), a viewpoint which permits us to study (and oppose) the public statements and the actual decisions of city planners, borough civil servants, elected officials and citizens' groups. As such, our research questions focus on the relationships between all the pertinent actors involved in "consensual planning". For example, the following questions arise regarding the relationships between the principal actors involved:

- How and why did the PIIA become the principal method of community resilience in the context of a rapid and difficult transformation of the neighborhood?

- What were the determining factors?

- What role did elected officials play in this context?

- How much did citizens participate in the process of public consultation?

We propose that the process of consultative planning led to a significant amount of consensus between the various actors and that the adoption of the PIIA bylaws has permitted a new and better adaptation of the system to the challenges it faced.

\section{Methodology}

Our methodological approach is that of a case study, qualitative and exploratory, largely inspired by documentary analysis and interviews, Over the course of time, we have accumulated extensive notes and have sought to document our observations principally with interviews with borough officials and to a lesser extent with the analysis of minutes of borough council meetings, submissions made to public hearings, articles in the local community newspaper, etc. In addition, we participated in the annual meetings of the Homeowners' Association, together with all special meetings dealing with public consultation on proposed PIIA bylaws $^{5}$. We also participated in discussions regarding the representativeness and role of persons named to the consultative committees on city planning, a voluntary committee of the Borough which presents recommendations to the Borough Council, including those to lift requirements imposed by the PIIA in particular situations.

\section{Research Problem and Background}

The Cité-Jardin du Tricentenaire à Montréal consists of 167 single family homes in the predominantly middle class Borough of Rosemont-La Petit-Patrie. The population of the neighborhood is distinctively upper middle class and is recognized as such. As one of the few examples of a garden city in North America, the Cité-Jardin du Tricentenaire became particularly interesting to study as the neighborhood

4 Our translation of "Collaborative Planning for Resilience", from Sandra Kaufman, 2012.

5 The PIIA (règlement 01-279-27) was adopted by le Conseil d'arrondissement de Rosemont- Petite-Patrie le January 17, 2011 and became law on March 1st of that year. Association des résidants de Cité-Jardin, Bulletin avril 2011. has undergone significant demographic transition over the past twenty-five years. Most of its original residents became senior citizens in the late 1980's and early 1990's, leading to an increasingly larger number of properties offered for sale (or less frequently, transferred to the next generation). While the earliest replacement families generally shared the community norms and values of the original residents, as real estate prices have risen dramatically, a new type of buyer has arrived who is increasingly interested in creating large, suburban-style housing close to the central city and to a variety of local venues: la Cité-Jardin is within walking distance of the metro and adjacent to Park Viau, the Botanical Gardens, the Insectarium, the Olympic Stadium, the Biodome, the MLS soccer campus, the Star-City cinema complex and the City of Montreal golf course. So given the economic value of residential "location", this neighborhood has a lot to offer.

The newly arrived residents have had a tendency to disregard the unwritten, social norms of the community. Frequently, they adopt renovation plans which do not integrate well with the original design of the Cité-Jardin du Tricentenaire nor do they seem to fit the social objectives of the original project of the 1940's. As may have been expected, the long term residents perceive these changes as a threat both to the physical, patrimonial character of the neighborhood and to community, social and environmental norms. While in some respects, the arrival of newcomers is similar to the invasion and gentrification of historic communities observed elsewhere in North America, the new arrivals are generally of the same social class (upper middle class professionals) and of the same ethnic origins as the original residents. The arrival of the newcomers with their desire to transform heritage architecture in terms of bulk, style, size and landscaping led us to question the impact of these changes on the long term population as well as the capacity of adaptation of the population of the whole area.

The original plan for the Cité-Jardin proposed three basic housing models, most of which subsisted with only modest renovation or additions into the early 1990's. The resistance of the long term residents was particularly focused on the issues of the enlargement of houses and their increasing deviation from the traditional models. As residential turnover increased, property values increased 300-400\% over the past fifteen years. Since property taxes are pegged to market value, the rapid increase in real estate values made it more difficult for people on fixed incomes, in particular the increasingly large number of retired residents, to afford continued residence in the area. This in turn has accelerated the rate of properties placed on the market as older residents "cashed in" on the rapidly rising home prices and avoided the payment of increasingly higher taxes. As both the number of homes available and the demand for such homes increased dramatically, real estate investors (or speculators) also began buying homes, in particular those which had undergone little or no renovation. They then began pressuring borough officials to recognize the legitimacy of demolishing these homes and constructing new ones, or alternatively, leaving 
only a fraction of the shell and constructing a new home. Consequently, the increased conflict between older and newer residents may be seen as disruptive of the social fabric in a way similar to that which occurs with a natural disaster, albeit that the process of disintegration was progressive.

To explore this aspect somewhat further, we examine in the next section one of the first sources of conflict between residents of the neighborhood and the beginning of public opposition, that of the proposal to abolish the paths (walkways) which link the various streets in the neighborhood, notably via the public park at the center of the neighborhood.

\section{The model of the Cité-Jardin under assault: the first public opposition to changes in the definition of community}

In the early 1980's, the City of Montreal decided that it no longer wished to maintain the pathways which linked together all the streets of the neighborhood. The original plan aimed to give the pedestrian's path responsibility to the residents and privatize them (the darkest shade on Figure 4), an action which would give larger lots to those who had property adjacent to the paths. In essence, the city tried to propose the abolition of most of the pathways, one of the essential characteristics of the neighborhood, although it did agree to maintain a certain number at its expense. Newer residents in general desired to increase the size of their property while older residents preferred to preserve the physical characteristics of the community.

The City first of all tried to sell a portion of the walkways to the adjacent property owners. However, while there was no official community organization, community norms were sufficiently solid that a vast majority of residents showed no interest in either purchasing or receiving lands which may have increased their tax bills and require additional maintenance efforts. Accordingly, the citizens rapidly came into conflict with city officials over this question.

Since the City could not, therefore, sell its pathways to the local population, it decided to rent the pathways for $\$ 0$ per year for a five year period to property owners on each side of the pathway, the pathway being divided down the middle. The City of Montreal hoped that eventually the impasse would be resolved. In fact, a large number of residents signed leases which gave them access to their half of the walkways, including the ability to fence off their portion, while not actually acquiring the land. As is shown in Figure 4, about half of the walkways were closed, freeing the city from its obligation of maintenance and permitting the residents to occupy the land without purchasing it. This being said, the incident created a good deal of mistrust between city officials and neighborhood residents.

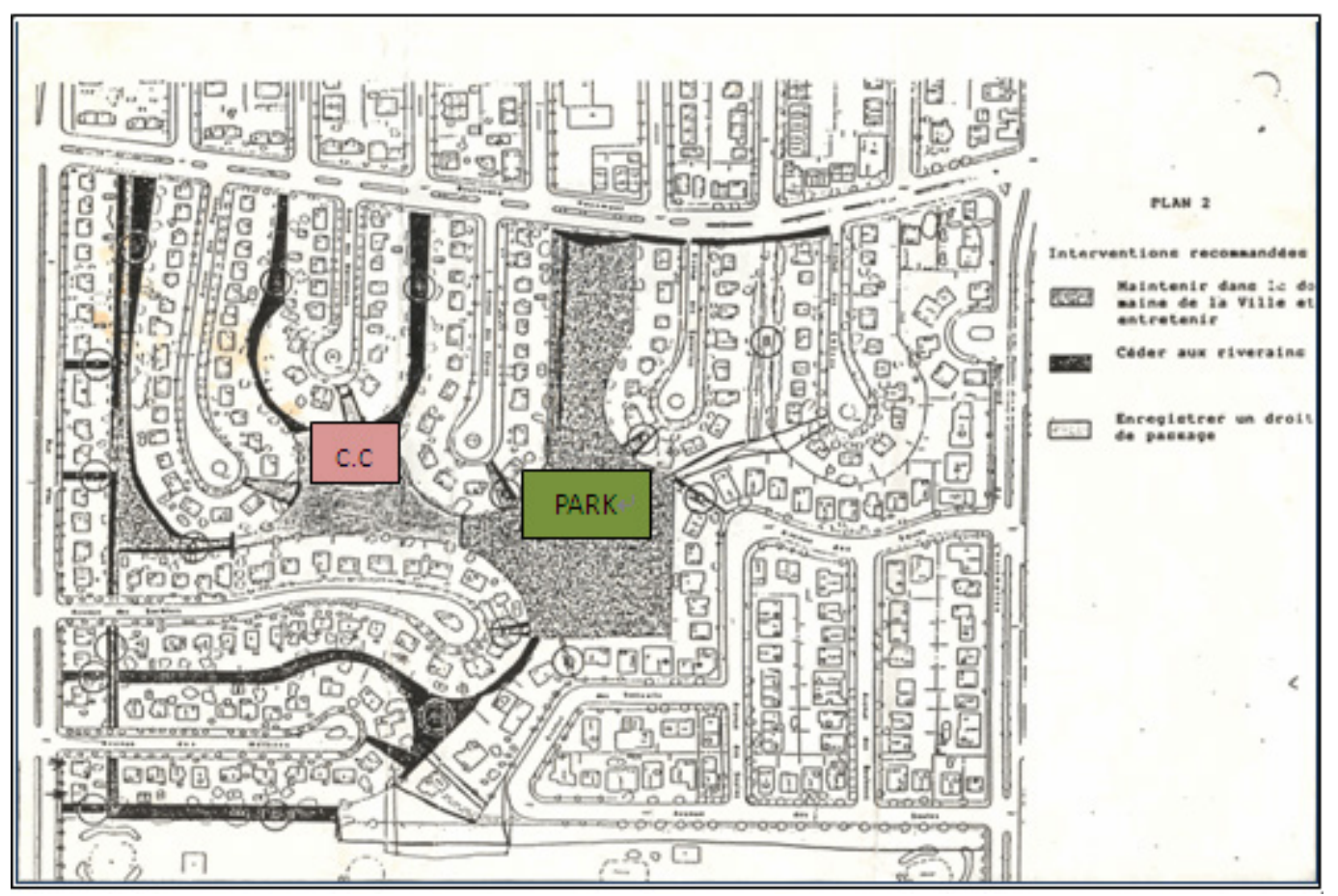

Figure 4. Plan of the pedestrian path system 


\section{The Citizen's Movement: the creation of the Residents' Association}

While the City of Montreal maintained its desire to eliminate more pathways, the long-term rehabilitation center (established in the original community center (C.C. on the map) announced its intention to fence its property, effectively closing three pathways leading to and from the community's central park. As a response to this new effort to circumscribe one of the defining characteristics of la Cité-Jardin, the « Association des résidents de Cité-Jardin » was created in 2004. After successfully resisting further encroachments on the pathway system, the residents' association also began to resist the major changes in housing size and type being sought by the newer residents. Aside from the desire to maintain gemeinschaft-type community relations, there were a number of important irritants in terms of respect for traditional architecture, the quality of the environment, landscape considerations and community heritage. Each of these factors was either directly or indirectly involved in what was becoming an important battle to preserve the historic character of the Cité-Jardin.

As part of its quest for legitimacy on the issue of heritage neighborhoods, the Residents' Association solicited support from the City of Montreal's Heritage Committee (Conseil du patrimoine). In spite of support from the Conseil ${ }^{6}$ and in flagrant disregard for the PIIA bylaws under adoption at that time by the Borough Council itself, one of the newcomers was permitted to renovate his home by tripling the size of the footprint on the lot size, doubling its volume and cutting all the mature trees on his property. This case contributed significantly to the resistance of the longer term residents to the permissiveness manifested by borough and city civil servants at the exact same time during which the PIIA was under development ${ }^{7}$

Nonetheless, as illustrated by this part of an interview with a long-time resident, the values of the newcomers and the long-timers do not converge on a number of issues:

«Reality has changed», says Carle Bernier-Genest, borough concillor. If he is fully conscious of the special characteristics of the Cité-Jardin neighborhood and shares « the desire of the residents to preserve the heritage characteristics of the Cité-Jardin, he hasn't forgotten that "new people constantly come to live in Montreal". He adds that " new owners don't have the same sensitivity to the heritage nature of the neighborhood as opposed to those who have lived there since its creation. »

http://www.journalderosemont.com/Environnement/20 09-02-10/article-929020/Le-quartier-CiteJardin-est-co

6 Conseil du Patrimoine, Cité Jardin A08-RPP-02, with respect to the projected renovations at 5601 des Cèdres.

7 At the Borough Council meeting of November 1, 2010, Councillor Élaine Ayotte gave notice that at the next session of Council she would propose the adoption of bylaws entitled « Règlement modifiant le Règlement d'urbanisme de l'arrondissement Rosemont-Petite-Patrie (01-279) » 7. These bylaws were designed to integrate both objectives and criteria within a PIIA framework to structure (« encadrer » in French), promote and preserve the heritage qualities of La Cité-Jardin du Tricentenaire. nfronte-a-une-nouvelle-realite/1, p.1, June, the 15 th 2012. (our translation).

As an example of the process of architectural transformation which has occurred, the house at 5120, avenue des Sorbiers, is instructive. After purchase, the house was abandoned for three years until such time as the new owner could persuade the borough that the building was structurally unsound and could not be rebuilt. Rumours within the community, whether true or not, suggested that the new owner deliberately weakened the foundations so that he could obtain a demolition permit. The new building resulted from a long negotiation with both the Borough of Rosemont-La Petite-Patrie and the City of Montreal. The architecture and bulk of the house have led to a lot of criticism within the community because it resembles a modern suburban " monster house " or "McMansion". In addition, the use of stone as material for use on the façade of the building is clearly prohibited in the PIIA bylaw.

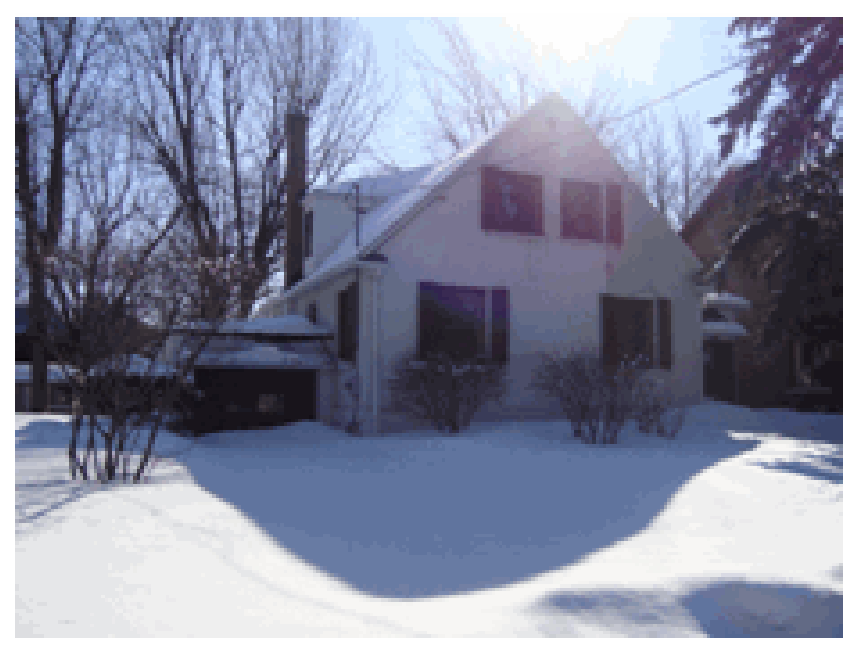

Photo 1. House (5120 ave des Sorbiers), December 2009

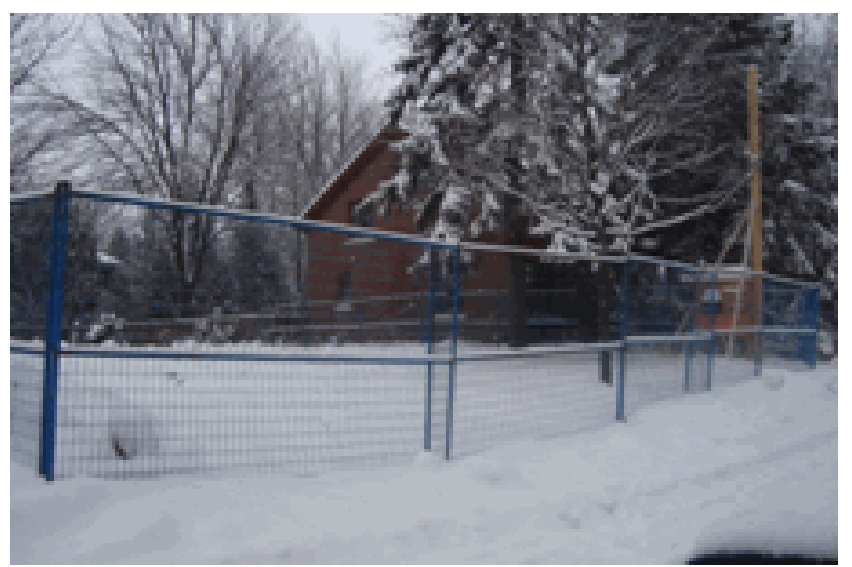

Photo 2. Vacant land after demolition, December 2010 


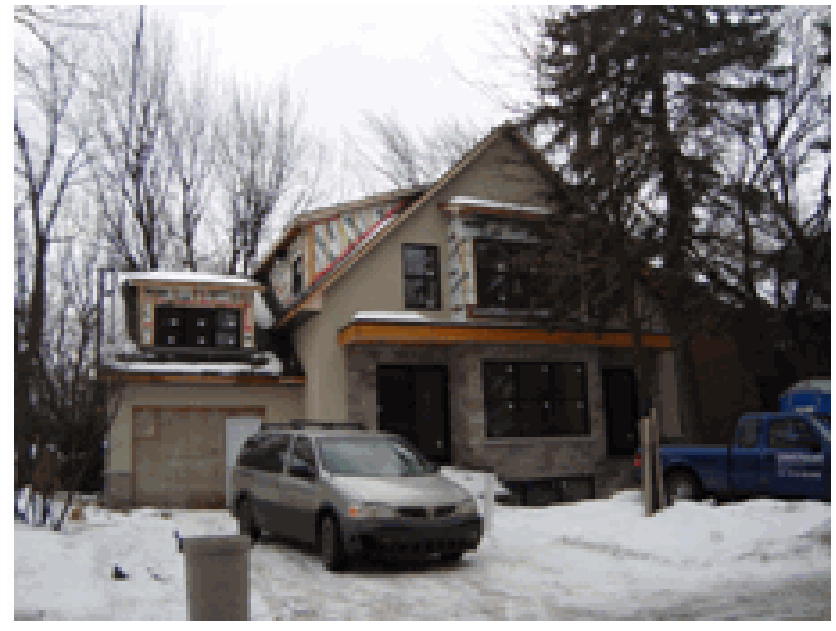

Photo 3. House rebuilt, December 2012

\section{The Creation of the "Plan d'implantation et d'intégration architecturale"}

In 2009 as a response to pressure from the Homeowner's Association, borough planners proposed a "Plan d'implantation et d'intégration architecturale" (PIIA) for the entire neighborhood. An informational meeting was called so that interested parties would be informed of the borough propositions regarding the housing footprint, landscaping, protection of existing vegetation and architectural considerations.

Citizen participation in the development of the PIIA Civil servants from the borough and members of the Association des résidants de Cité-Jardin consulted regularly on the development of the PIIA bylaws, including the housing footprint, landscaping, protection of existing vegetation and architectural considerations. One of the proposed bylaws limited the housing footprint for the first-floor to $35 \%$ of the lot size. As part of the PIIA process, consultations were held in 2009 to reduce this proportion to $25 \%$, a proposition vigorously supported by the older residents but equally vigorously rejected by the newcomers. The proposition caused tremendous conflict and tension within the Homeowner's Association but by 2009, long term residents no longer formed a clear majority.

In addition, the long term residents resolutely opposed additional transfers of the city's pathways to the adjacent residents because this would permit newcomers to build their $35 \%$ footprint on a larger lot size. As it was, most of the older homes occupied less than $25 \%$ of the lot size whereas most of the newer renovations occupied the entire 35\% (and sometimes more, once again highlighting the uneven application of the PIIA norms). Should the city have succeeded in transferring its pathways, future houses could be still larger. In spite of the attempts by the newer residents to persuade the longer term residents to accept the city's offer to transfer the pathways, the community, patrimonial and environmental norms defended by these latter were sufficiently strong to resist such efforts. The City finally declared a moratorium on the question, although it still wishes to close the pathways and eliminate the maintenance involved.

A group of consultants, Convercité, was hired by the borough to plan an informational meeting, followed by a series of discussion groups with local residents. The informational meeting was attended by one or more members from thirty-eight households, i.e., one quarter of the total, while one or more members from twenty-eight households participated in the discussion groups. Therefore, it would not appear, that the residents of Cité-Jardin were as actively engaged in the process as might have been expected. That being said, the level of participation was sufficiently high that the relative size of the two competing groups, the newer owners and the long term residents, could be better measured, both groups providing spirited defenses of their positions in approximately equal numbers. We conclude, therefore, that the work of Convercite served as a mechanism for assuring that there was a maximum of consensus regarding the content of the PIIA. The long term residents maintained the existing property size but the newer residents were assured the continuity of the $35 \%$ footprint.

Thus, the adoption of the PIIA (Plan for Architectural Integration and Establishment) in 2011 created new bylaws designed to help protect the original qualities of the Cité-Jardin du Tricentenaire. One may conclude that the process of public hearings and consultation seems to have contributed to a better understanding of the historical and heritage value of the Cité-Jardin without, however, having convinced new property owners of the importance of conserving both the character and the volume of their residences when proposing renovation projects.

There can be no doubt that the development of the PIIA and the process of public consultation adopted by the Borough and the City ended the architectural anarchy which characterized the period of the late 1990's and the decade 2000-2009 by providing a certain number of guidelines and requirements. However, it was impossible to obtain consensus on the important item of the housing footprint, a point which was extremely important to the long term residents defending the patrimonial character of the neighborhood. Of the 167 properties in the neighborhood, $29^{8}$ (Figure 5) exceeded a footprint of $25 \%$ and this number may be expected to increase regularly as long term residents continue to sell their homes, motivated by an increasing demand for housing in this neighborhood, particularly since it is now well established that the footprint and volume of renovated housing can be easily increased.

8 At least eight more properties now exceed this limit, having been renovated since 2009 . 


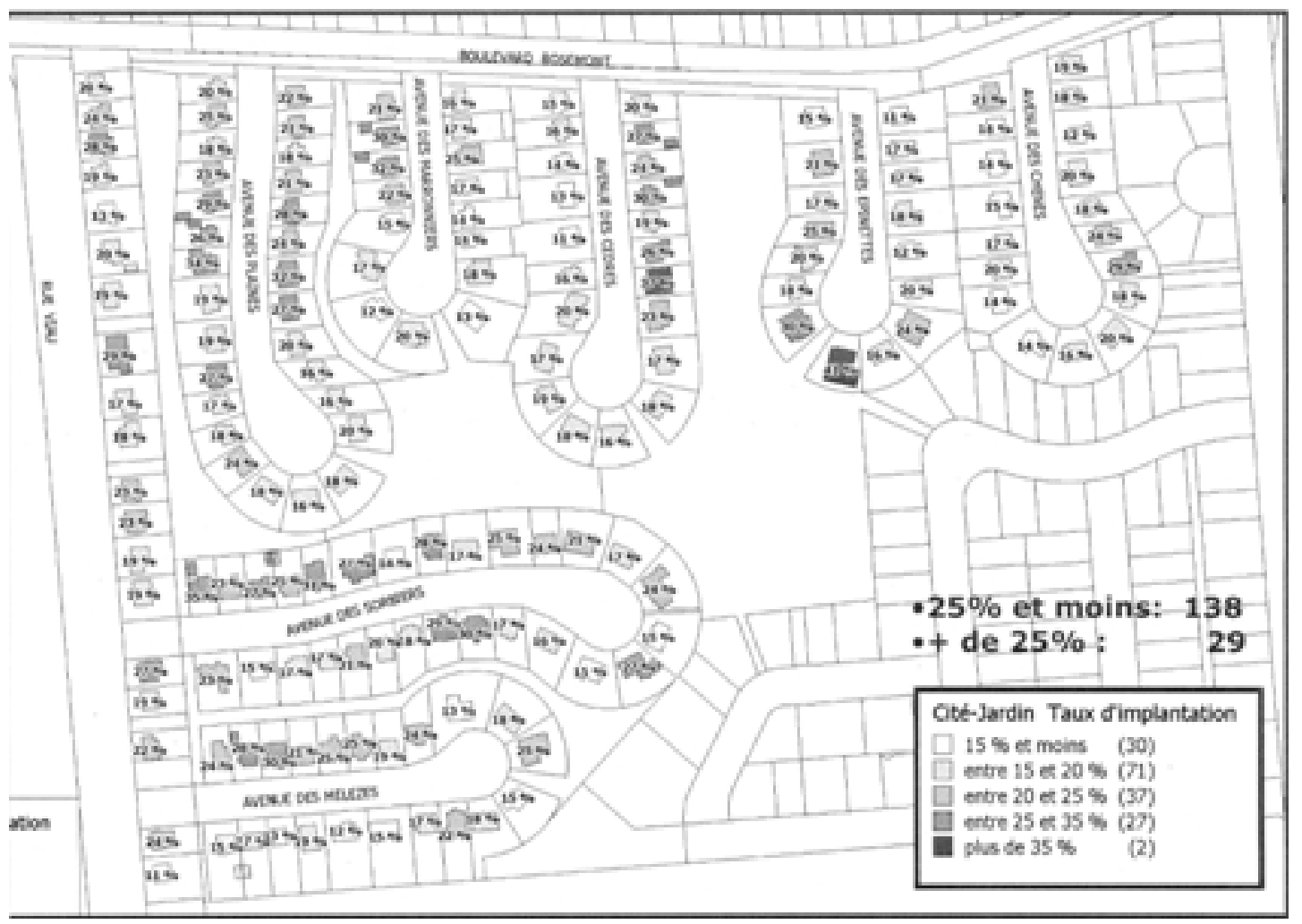

Source: City of Montréal, « La Cité Jardin du Tricentenaire, Un paysage à protéger », Colloque sur les sites et la citation de monuments d'intérêt patrimonial, June 12 th, 2009, p.23.

Figure 5. Housing Footprints in the Cité-Jardin du Tricentenaire, 2009

As a result of the PIIA bylaws, the newer residents have started to better understand the meaning of this particular site in the history of Montreal urban planning, although it is fair to say that its implementation has been less than perfect and the cultural clash between the original residents and the newcomers has not entirely been resolved.

\section{The creation of a Visual Guide for PIIA Project Proposals}

The adoption of PIIA bylaws has not led to a consistent application of its formal requirements. Since its adoption, a certain number of projects presented by newer residents continue to trouble many of the long term residents, particularly those which authorize the cutting of trees and which appear to authorize unduly large houses, given the required 35\% limit on housing footprints. In Montreal, each proposed permit to construct or modify a residence must first receive the benediction of a Citizen's Advisory Committee on urban affairs (le Comité consultatif d'urbanisme). Such a recommendation may include the acceptance of criteria which deviate from regulations. Even when recommendations are made which conform strictly to the standard, the Borough Council is not bound by the CCU recommendations and may authorize projects which are in some respects deviant. With respect to the Cité-Jardin, the mayor of the Borough is also president of the $\mathrm{CCU}$ so that in most cases we expect that there should be little difference between CCU recommendations and those adopted by Council.
Given the fact that some projects approved by Council seemed contrary to one or more of the PIIA bylaws, the Executive Committee of the Resident's Association began to promote the idea of creating a visual guide to what should or should not be done when proposing projects to renovate existing homes. Their objective was to make it clear to newcomers what is expected in terms of respecting both the spirit and the letter of the PIIA bylaws. Once again, borough officials worked together with the Executive Committee and a visual guide was published in early $2013^{9}$.

\section{Is the PIIA the key factor in the process of urban resilience? Further analysis.}

At the level of the Borough

With respect to the subject of heritage architecture, the Borough of Rosemont-La Petite-Patrie makes it very clear to new property owners or to anyone who would like to modify their homes that:

«... a great number of buildings have qualities which command their preservation. If your property is located in a designated area for architectural preservation, get information before starting any exterior renovation: you might need a specific permit which takes some time to process.» ${ }^{10}$

9 In last March 2013, Rosemont-la Petite-Patrie published a guide for résidents of Cité-Jardin du Tricentenaire about what should or should not be done architecturally in the area.

10 Our translation of Site de la ville de Montréal : 
The document also states that certain sectors of the Borough may be covered by a PIIA, a situation designed to favor architectural quality and a certain degree of harmony with the surrounding neighborhood.

\section{Perceptions of Elected Officials}

The official position of the Borough of Rosemont-La Petite-Patrie is made exceptionally clear in its published literature:

"In the Borough, all new constructions or enlargement
(residential and commercial projects) are subject to an
architectural and integration plan (PIIA)). The PIIA is
an additional tool for the evaluation of a real estate
project. It allows through qualitative measurement
criteria, a better integrated architecture in its area." "

This being said, the actual application of the PIIA bylaws is not nearly so rigorous. When interviewed on this subject, Marc-André Gadoury, one of the borough council members, remarked that conflicts between residents over extensive transformations of the housing stock is not a recent phenomenon and that the City had been involved in conflictual relations with property owners for a long time. This is, consequently, a subject which a new municipal administration is required to treat with a certain amount of prudence. Since, however, the current borough administration is part of a progressive, municipal party, one may ask with a certain amount of legitimacy whether this administration is willing to go somewhat further than previous ones to ensure the preservation of the heritage quality of the neighborhood. While M.-A. Gadoury recognizes that there remains significant differences of opinion among the residents of Cité-Jardin with respect to the content and utility of the PIIA, he feels that the bylaws represent a tool to promote greater harmonization of projects with the original character of the neighborhood while at the same time leaving the door open to a certain degree of negotiation between borough officials and the promoter of a specific project.

Similarly, the mayor of the borough, François-William Croteau, stated that most residents who desire to modify and/or renovate their homes in the neighborhood are able to negotiate a mutually satisfactory agreement with borough officials and the CCU within the general framework specified by the PIIA bylaws. M.-A. Gadoury observed that the $\mathrm{CCU}$ enjoys considerable latitude when applying the bylaws. In his view, the PIIA was not designed as a reactionary tool nor was its objective to preserve every building in its current state. Rather, the PIIA is a significant tool for negotiating with residents who wish to modify their current building. From both of these interviews, we conclude that the Borough has adopted negotiation as a strategy for

http://ville.montreal.qc.ca/portal/page?_pageid=7357,75803654\&_dad=por tal\&_schema=PORTAL, January 15 th, 2013.

11 Site de la ville de Montréal :

http://ville.montreal.qc.ca/portal/page? pageid $=7357,75803654 \&$ dad $=$ por tal\&_schema=PORTAL, January, 15th, 2013. dealing with each individual project rather than attempting to apply the prescriptions of the PIIA in a rigorous manner.

According to the Mayor, most requests for modification of existing housing in the Cité-Jardin are relatively minor. However, most of the projects designed to create "monster houses" are presented by residents who are not inclined to negotiate changes with borough officials and the CCU. These projects are simply refused by the Borough Council until such time as the promoters decide that they have no other recourse than to follow the standard procedures. It would appear, according to M.-A. Gadoury, that most of these projects originate from new home owners just arriving in the community who take their inspiration from successful creations of high footprint, high volume buildings in the recent past. His understanding is that most of these people are not suburbanites wishing to impose their housing standards on the neighborhood but urbanites who wish to create such houses within a unique urban setting.

The mayor also noted that in Quebec, the line delimiting public and private interest with respect to real estate may be rather fluid and hence, a further justification for negotiation regarding the interpretation and application of the PIIA bylaws. This, obviously, is the question which has been motivating the conflict between residents for the past twenty-five years. At what point does the right of private property take precedence over the right to preserve the architectural and heritage qualities of one of the unique Garden Cities in North America? The mayor considers that the Borough should position itself as mediator of the two concepts, using the PIIA as a tool to help the reluctant newcomer better integrate his project into the existing neighborhood. Nonetheless, the Mayor firmly believes that his administration, affiliated with the progressive party, Projet Montréal, is more firmly committed to the preservation of the heritage quality of the neighborhood than have been preceding administrations. For example, several months before the adoption of the PIIA, the Mayor ordered city officials to apply the new bylaws so that the Borough would not receive an avalanche of new applications designed to circumvent them. At the same time, the Mayor recognizes that there is a certain subjectivity to the application of the PIIA bylaws. The judgments and interpretations of the architects and technicians of the borough concerning architectural quality and specific aspects of projects do not always satisfy the various opinions which subsist in the neighborhood.

In fact, according to the Mayor, the importance of the situation in the Cité-Jardin is the direct result of the pressure exerted by the Homeowner's Association to protect the heritage quality of the neighborhood. When it became clear that the informal social pressure exerted by the community norms of gemeinschaft could no longer protect the community from the individualistic projects of new property owners, the Residents' Association turned to the public sector for help. It is now the Borough which assumes responsibility for assuring the future of the neighborhood, The mayor also observed that the Residents' Association has 
progressively retreated from its original militant positions on heritage architecture as more and more of the newer home owners became members. Attempts to retain a militant preservationist approach created even greater frictions within the community. The mayor maintains that borough officials obtain what they feel is the maximum amount of conformity to PIIA standards for each project but that there will always be some difficulty since the Borough cannot completely restrain the rights of particularly tenacious property owners ${ }^{12}$.

Finally, the Mayor noted that even heritage neighborhoods are compelled to undergo some evolution. The best that the Borough can do is to create a certain amount of social peace with its PIIA. It is with this perspective in mind that the Borough, in partnership with the Homeowner's Association, created the visual guidebook for residents of the Cité-Jardin, a document which explains the history and heritage characteristics of the neighborhood and illustrates the various options which homeowners may adopt when proposing to modify their homes. Once again, the goal is to minimize social friction within the neighborhood by taking a proactive approach.

In conclusion, it would appear that the public discourse of the elected officials we interviewed conforms well to the Borough's understanding of its PIIA, i.e., that its principle function is to foster negotiation with property owners and circumscribe the limits of prospective changes to the property. If there has been any change in public discussion by elected officials, it would appear to be in favor of the preservation of the heritage neighborhood at the expense of the rights of private property. However, it is very important to understand that a PIIA has limited power; its application is governed by a consultative committee and only the Borough Council has final power to approve projects. It is for this reason that the application of PIIA criteria nonetheless permits certain anomalies in terms of its global impact.

\section{Conclusions}

We have examined in this paper the course of social disruption similar to the process of resilience occasioned by the arrival of new residents in the Cité-Jardin du Tricentenaire. As the newer residents no longer conformed to the community standards of architectural and environmental preservation, the longer term residents organized to defend the heritage characteristics of the neighborhood. They created the Homeowner's Association in 2004 in order to combat perceived encroachments on community norms. They then began to pressure the borough to preserve the characteristics of a Garden City, to which the borough responded with the development and adoption of the PIIA in 2011. The PIIA attempts to preserve the quality of the neighborhood for future generations by limiting the amount and types of transformation allowed. This is not to

12 There are at least three pending court cases by newcomers challenging the authority of the Borough to implement PIAA standards. say that the PIIA has completely solved the conflicts between the two groups.

To a certain extent, elected officials not only have adopted the discourse of preservation; they even imposed the implementation and procedures of the PIIA before it was formally adopted, demonstrating the determination of the Borough to ensure the long term durability of their heritage neighborhood within the general framework of community architecture and landscape.

The mayor and Borough councillors have consistently spoken in favor of preservationist values, which is still more important considering that the mayor is also the president of the CCU (Advisory Council). He thus participates as an advisor on proposed projects and as executor in his capacity as mayor. With respect to citizen participation in the process, a quarter of the residents participated actively in the preparation of the PIIA, a standard which is quite respectable when compared to most public hearings and consultation. Needless to say, the participants were generally militants in favor of either preservationist or property rights values, two perspectives which were generally in opposition much of the time.

With respect to our hypothesis of a return to a consensual framework, i.e., to stability, we can only assume partial verification. The process of city planning which led to the PIIA, guided by an external consulting firm, clearly established a certain level of consensus between the two community groups. It would, however, appear that there was a significant degree of collaborative planning to ensure the longer term stability of the heritage area.

Nonetheless, there remains significant disagreement regarding the utility and implementation of the PIIA standards and their long-term effectiveness in preserving the original vision of Ebenezer Howard. With respect to environmental quality and the architectural characteristics of the neighborhood, most of the longer term residents are not always impressed by the results of the PIIA. Even if the city and the Borough continue to talk "preservation", a number of authorized renovations seem still to be largely out of step with neighborhood standards. In addition, there are at least three pending court cases by newcomers challenging the authority of the Borough to implement PIAA standards. "Too little, too late" would seem more to characterize the state of resignation of the longer term residents for whom the continued transformation of housing and environment contributes to the erosion of cultural values and social solidarity, a progressive decline of gemeinschaft and the consequent rise of gesellschaft (communalisation vs sociation).

\section{REFERENCES}

[1] BLAIS, Marie (2013) «La mixité sociale : le cheval de Troie de la gentrification? » Nouveaux cahiers du socialisme, no 10, automne 2013, 75-85. 
[2] CHOKO, Marc-Henri (1988) Une cité-jardin à Montréal, coll. Histoire urbaine Montréal: Éditions du Méridien, 271 p.

[3] CORBOZ, André (2000) "Ville Mont-Royal, cité-jardin vitruvienne». Journal de la société pour l'étude de l'architecture au Canada, vol 25, no. 2, 3-16.

[4] COLLIN, Jean-Pierre (1986) La cité coopérative canadienne-française, Saint-Léonard de Port-Maurice, 1955-1963, Montréal INRS-PUQ, 184 pages.

[5] GILLILAND, Jason A. (1996) «Transforming the Ideal: Visions and Revisions of Housing in a French-Canadian Community, 1942-1995», Mémoire de maîtrise, School of Architecture, McGill University, 225 p.

[6] HOWARD, Ebenezer (1902) Garden Cities of To-morrow. London, Swan Sonnenschein \& Co., 167 p.

[7] JÉBRAK, Yona (2010) « La reconstruction et la résilience urbaine: l'évolution du paysage urbain », thèse de doctorat en Études urbaines soutenue en vue de l'obtention du grade en 2010, 420 p.

[8] MUMFORD, Lewis (1961) The City in History: Its origin, its transformations and its prospects. Harcourt: Brace and World, $657 \mathrm{p}$.

[9] PARÉ, Sylvie (2011) Dealing with Residential Turnover and Transition: the Case of Montreal's Cité-Jardin-du-Tricenten aire, texte de la conference UAA 2011, présenté lors de la conférence annuelle, mars 2011.

[10] PARÉ, Sylvie (2012) «Perspective citoyenne et enjeux liés à la transition du quartier Cité-Jardin-du-Tricentenaire à Montréal » dans Luc-Normand Tellier et Carlos Vainer, Presses de l'Université du Québec

[11] PARÉ, Sylvie (2012) « La transformation de la Cité-Jardin du
Tricentenaire à Montréal : quelle résilience urbaine ?», $L a$ revue de CENEAP, no 45, 23-37.

[12] POLÈSE, Mario (2010) The Resilient City: On the Derterminants of Successful Urban Economies, INRS-UCS, Document de travail, $32 \mathrm{p}$.

[13] VILLE DE MONTRÉAL « La Cité Jardin du Tricentenaire, Un paysage à protéger », Colloque sur les sites et la citation de monuments d'intérêt patrimonial, 12 juin 2009, p.23.

[14] WOLFE, Jeanne (1981) The Progress of Housing Reform: Three Early experiments in Montreal, McGill, 26 pages.

[15] WOLFE, Jeanne (1994) « Retour sur le passé: un survol historique de l'urbanisme canadien », Plan Canada, no 6 , $2-36$.

[16] www.resalliance.org- Resilience alliance 2011, March the $8^{\text {th }}$, 2011.

[17] www.lesbeautesdemontreal.com/2010/06/17/les-belles-de-m on-quartier/, August the $28^{\text {th }}, 2011$.

[18] http://ville.montreal.qc.ca/pls/portal/docs/PAGE/CONSEIL PATRIMOINE_MTL_FR/MEDIA/DOCUMENTS/A08-RP P-02.PDF, August the $28^{\text {th, }} 2011$.

[19] www.montrealexpress.ca/Societe/Environnement/2009-02-1 0/article-1547513/Le-quartier-Cite-Jardin-est-confronte-a-un e-nouvelle-realite/1-Le quartier Cité-Jardin est confronté à une nouvelle réalité, 10 Février 2009, August the $28^{\text {th }}, 2011$.

[20] http://fr.wikipedia.org/wiki/Ebenezer_Howard, August the $28^{\text {th, }} 2011$.

[21] http://www.journalderosemont.com/Environnement/2009-02 -10/article-929020/Le-quartier-CiteJardin-est-confronte-a-un e-nouvelle-realite/1, p.1, June the 15th, 2012. 